\title{
Erratum to: The Use of Rock Mass Classification Systems to Estimate the Modulus and Strength of Jointed Rock
}

\author{
J. L. Justo $\cdot$ E. Justo $\cdot$ J. M. Azañón • \\ P. Durand $\cdot$ A. Morales
}

Published online: 2 December 2009

(C) Springer-Verlag 2009

\section{Erratum to: Rock Mech Rock Eng}

\section{DOI 10.1007/s00603-009-0040-6}

Page 6, lines 2 and 3 in the text: the sentence "; in other cases negative moduli were obtained (Barton 2002; Kayabasi et al. 2003)" should be deleted.

The online version of the original article can be found under doi:10.1007/s00603-009-0040-6.

J. L. Justo $(\bowtie) \cdot$ E. Justo · P. Durand · A. Morales

Department of Continuum Mechanics, University of Seville,

E.T.S. Arquitectura, Avenida Reina Mercedes 2,

41012 Seville, Spain

e-mail: jlj@us.es

J. M. Azañón

Department of Geodynamics, University of Granada,

Granada, Spain 